\title{
Lipid-peptide bioconjugation through pyridyl disulfide reaction chemistry and its application in cell targeting and drug delivery
}

\author{
Diego de la Fuente-Herreruela1,2, Ajay K. Monnappa ${ }^{3}$, Mónica Muñoz-Úbeda², Aarón Morallón-Piña', \\ Eduardo Enciso ${ }^{1}$, Luis Sánchez ${ }^{4}$, Fabrice Giusti ${ }^{5}$, Paolo Natale ${ }^{1,2}$ and Iván López-Montero ${ }^{1,2^{*}}$ (])
}

\begin{abstract}
Background: The design of efficient drug delivery vectors requires versatile formulations able to simultaneously direct a multitude of molecular targets and to bypass the endosomal recycling pathway of cells. Liposomal-based vectors need the decoration of the lipid surface with specific peptides to fulfill the functional requirements. The unspecific binding of peptides to the lipid surface is often accompanied with uncontrolled formulations and thus preventing the molecular mechanisms of a successful therapy.
\end{abstract}

Results: We present a simple synthesis pathway to anchor cysteine-terminal peptides to thiol-reactive lipids for adequate and quantitative liposomal formulations. As a proof of concept, we have synthesized two different lipopeptides based on (a) the truncated Fibroblast Growth Factor (tbFGF) for cell targeting and (b) the pH sensitive and fusogenic GALA peptide for endosomal scape.

Conclusions: The incorporation of these two lipopeptides in the liposomal formulation improves the fibroblast cell targeting and promotes the direct delivery of cargo molecules to the cytoplasm of the cell.

Keywords: Smart liposomes, Disulfide bonds, Targeting peptide, GALA, Endosomal escape

\section{Background}

Liposomes have been extensively used as delivery vectors for pharmaceuticals as they have a series of advantages over other molecular release systems [1]. Liposomes are non-toxic, and completely biodegradable and do not exhibit immunogenicity [2]. Their phospholipid bilayer envelope provides both hydrophobic and hydrophilic moieties for a diverse kind of active cargo molecules, increasing their stability and reducing their toxicity. In addition, liposomes are versatile scaffolds with tunable physicochemical properties. The thousands of lipid species [3] can be used to tailor the specific requirements

\footnotetext{
*Correspondence: ivanlopez@quim.ucm.es

${ }^{1}$ Dto. Química Física, Universidad Complutense de Madrid, Avenida

Complutense s/n, 28040 Madrid, Spain

Full list of author information is available at the end of the article
}

for improved delivery. Spontaneous curvature [4], bending rigidity [5], dilational elasticity [6], membrane fluidity [7] or surface charge [1] are easily controlled through the lipid composition.

The controlled and selective delivery of compounds into cells is a key element of targeted drug delivery therapies. Major innovations in liposome technology were achieved by triggered-release strategies using activating sources such as $\mathrm{pH}$, ultrasound, heat or light $[8,9]$. The drug release can be time regulated and locally restricted to specific sites with suitable formulations including externally switchable molecules. In practice, they are, however, been difficult to engineer. The new generation of smart liposomes takes advantage instead of wellcontrolled biochemical switches already provided by the targeted cells. This implies the surface modification of 
liposomes with passive or active targeting approaches and improved intracellular delivering systems [1].

A paradigmatic strategy of passive targeting consists on the incorporation of PEGylated lipids in the liposomal composition to avoid the detection by the host immune system [10]. PEG-grafted liposomes improve the residence time in the blood circulation, as compared to conventional liposomes [11]. Active targeting is based on cellular receptors that are found on surface of the target cell and demands the modification of the liposomal surface with specific molecules able to recognize or bind the present surface receptors. After cellular uptake, liposomes are usually trapped in endosomes $[12,13]$ and not able to release their therapeutic cargos within the cell. Numerous formulations take advantage of the acidic medium of the endosomes and include specialized $\mathrm{pH}$ dependent fusion peptides to promote endosomal escape [14-16]. Combined strategies improve simultaneously the ability of liposomes to accumulate on the target cell and the uptake of the active drug in the lumen of the cell [17].

The surface functionalization of liposomes is an important step to improve their delivery efficiency. The very reactive sulfhydryl group of cysteine amino acid residues allows the conjugation of cysteine containing-peptides through classical sulfhydryl-reactive crosslinkers or thiol reagents. The thiol is susceptible to oxidation promoting the formation of a thioether or disulfide bonds. The first reaction can be achieved with high concentration of maleimides following a Michael addition reaction to form succinimide thioethers derivatives or in the presence of haloacetyls (iodoacetimide) reagents following nucleophilic substitution [18]. However, the succinimide bond can be hydrolyzed spontaneously thus losing the binding between the peptide and the ligand [19]. Peptide bioconjugation based on the formation of disulfide bonds, where the cysteine groups react with pyridyl disulfides reagents, produces a labile disulfide bond in both redox and hydrolytic conditions but only potentially cleaved due to action of thioreductases enzymes in biological contexts [20].

Here we present a straightforward synthesis pathway to anchor peptides with terminal cysteine residues to sulfydryl-reactive lipids for adequate and quantitative liposomal formulations. Based in the pyridyl disulfide reaction chemistry [21], we have functionalized lipids with (a) a truncated Fribloblast Growth Factor (FGF) for cell targeting and (b) a pH sensitive fusogenic peptide (GALA) for endosomal escape. The basic fibroblast growth factor (bFGF) is one of the 23 multifunctional proteins belonging to the family of fibroblast growth factors that binds to the FGF surface membrane receptors (FGFRs) [22] and widely used as a targeting molecule due to its mitogenic, chemotactic and angiogenic activities promoting the rapid proliferation of cells. The truncated bFGF (tbFGF) is a 9-amino acid peptide that includes a cysteine in the carboxy terminal end (NH2-KRTGQYKLC-COOH) [23] and although it is able to bind to FGFRs it is not able to induce cell proliferation [24-26].

The GALA peptide (NH2-WEAA-LAEA-LAEA-LAEH-LAEA-LAEA-LEALAA-COOH) is a member of the $\mathrm{pH}$-sensitive peptide family $[27,28]$ and originates from the amino terminal segment of the $\mathrm{H} 2 \mathrm{~A}$ subunit of hemagglutinin from the influenza virus $[25,29,30]$. At low $\mathrm{pH}$ (i.e. $\mathrm{pH}=5$ ) the GALA peptide organizes into an amphipathic alpha helix partitioning the amino acid side chains into a hydrophilic or a hydrophobic surface. This reorganization promotes the self-oligomerization of 10 peptides [31] that is able to penetrate into the hydrophobic core of lipid membranes forming pores with a diameter of 5-10 $\AA[17,25]$. At physiological and basic $\mathrm{pH}(\mathrm{pH}>7)$ the GALA peptide presents a random coil configuration and exhibits no membrane activity [28]. Triggered by the acidic medium within the lumen of the endosomes, it has been shown that GALA effectively penetrates and permeates cell lipid bilayers and allows the endosomal escape during the internalization of drugs into the cytosol via endocytosis $[28,31]$.

As a proof of concept, our results show that the incorporation of both synthesized bioconjugated lipopeptides in liposomal formulations improved the cell targeting and promoted the direct delivery of cargo molecules in the cytosolic moiety of cultured mouse embryonic fibroblasts (MEFs).

\section{Results}

\section{Lipid-peptide conjugation through pyridyl disulfide reaction chemistry}

The cysteine-containing tbFGF and a variant of the GALA peptide (GALA-Cys, carrying the cysteine residue at the carboxy terminal end) were conjugated to the thiol-reactive lipid 1,2-dipalmitoyl-sn-glycero3-phospho-thio-ethanol (DPTE) accomplished with two pyridyl disulfide exchange reactions (Fig. 1). A first disulfide exchange occurs between 2-2-pyridyl disulfide (DPDS) and the thiol group of DPTE in acidic conditions (see "Methods"). After purification of the activated DPTE (aDPTE), the disulfide bridge formed by DPTE and 2-mercaptopyridine is substituted by DPTE and the cysteine-containing peptide at molar ratio of 1:2 (DPTE:peptide-SH) (see "Methods"). Although the optimal $\mathrm{pH}$ for disulfide exchange ranges from 4 to 5 , the second disulfide exchange was performed at alkaline $\mathrm{pH}$ 9, above the pKa of cysteine residues (Additional file 1: Figure S1), to force the cysteine residue of the peptides to react. Furthermore, the reaction was performed in a mixture of tetrahydrofuran (THF) and $1 \mathrm{M}$ Tris $\mathrm{HCl} \mathrm{pH}$ 


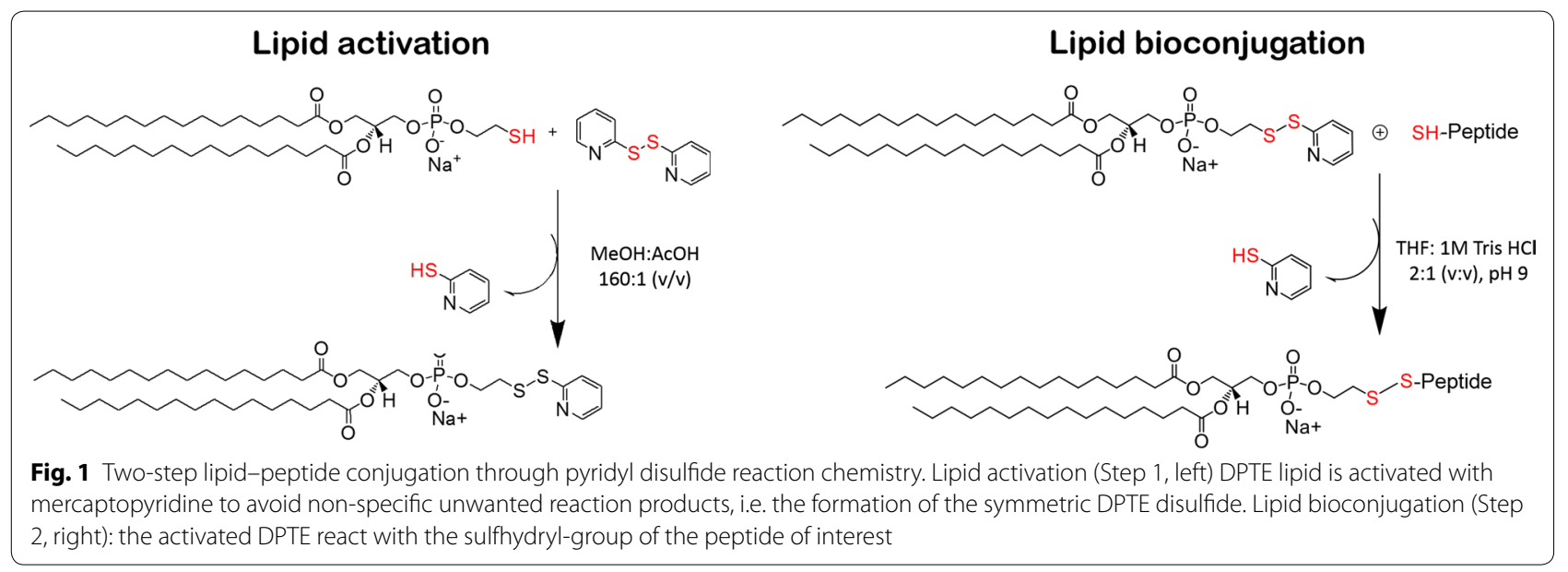

9 (2:1; vol:vol) under stirring conditions for $48 \mathrm{~h}$ at $20^{\circ} \mathrm{C}$ in the dark. This solvent mixture ensures the solubility of both the hydrophobic lipids and the charged peptides in a buffered medium. The course and progress of this reaction can be measured spectrophotometrically $\left(\mathrm{A}_{\max }=363 \mathrm{~nm}\right)$ monitoring the release of the byproduct pyridine-2-thione [32]. The disulfide exchange takes place within the first $10 \mathrm{~min}$ where the reaction kinetic reaches a pseudo-plateau indicating a slower reaction rate (Additional file 1: Figure S2A). The reaction mixture was left up to $48 \mathrm{~h}$ in the dark to fully complete the reaction. After purification of the DPTE-peptide, the reaction intermediates and final products were dissolved in deuterated chloroform and characterized by ${ }^{1} \mathrm{H}$ NMR spectroscopy (see Additional file 1: Figure S2B and "Methods" for details). Finally, the lipid to protein ratio of the lipopeptide conjugation was determined by Rouser [33] and Lowry [34] assays respectively (see "Methods" for details) giving a $100 \%$ and $95 \%$ conjugation efficiency for the DPTE-tbFGF and DPTE-GALA respectively.

\section{POPC vesicles containing DPTE-tbFGF and DPTE-GALA}

To characterize the lipid concentration, the lipopeptide molar fraction, the size and the stability of liposomes, different molar ratios of DPTE-tbFGF and/or DPTE-GALA were incorporated into pure POPC vesicles. As some lipid loss might occur during extrusion [35], the lipid concentration was quantified before and after extrusion down to the size of $0.1 \mu \mathrm{m}$. The phosphorous analysis [33] did not detect significant loss of lipids during liposome preparation, as shown in Additional file 1: Table S1. Similarly, the molar fraction of lipopeptides was not altered during extrusion (Additional file 1: Table S1). The results obtained from the size characterization are shown in Fig. 2a. The light scattering results show that the incorporation of DPTE-tbFGF and DPTE-GALA in POPC liposomes does not affect substantially the size of the liposomes. All formulations had mean diameters around 150-200 nm immediately after extrusion and retained this size for several days. This indicates that no fusogenic nor aggregating activity of peptides is occurring at $\mathrm{pH}$ 7.4. However, the surface charge of POPC liposomes $(\sim 0 \mathrm{mV})$ is altered upon incorporation of the negatively charged peptides and a decrease in the $\zeta$-potential is evidenced ( $\leq 20 \mathrm{mV}$ ) (Fig. 2b).

\section{Cell viability upon liposomal incubation with different molar ratios of DPTE-tbFGF and DPTE-GALA}

We use the alamarBlue cell viability assay to assess the cell viability of mouse embryonic fibroblasts (MEFs) exposed to POPC liposomes at 50, 75 and $100 \mu \mathrm{M}$ and decorated with different molar ratios of the lipid-peptide conjugates (DPTE-tbFGF and DPTE-GALA). Figure 3 shows the cell viability results for different molar ratios of the DPTE-peptide conjugates at 50, 75 and $100 \mu \mathrm{M}$ liposome concentration. None of the used lipid compositions or liposomal concentrations explored showed a significant effect on cell viability ( $p$ value $<0.05$ ). In general, the liposomes do not induce a significant cell death $(>$ than $20 \%$ in extreme cases) nor do they stimulate the proliferation of MEFs. Overall, both DPTE-peptide conjugates are biocompatible, not harmful for cell viability, and thus safe to use for ex vivo MEF cultures. For following experiments with cultured MEFs we fixed the liposome concentration at $100 \mu \mathrm{M}$.

\section{Liposomal uptake of tbFGF-coated liposomes by cultured MEFs}

We first tested the increased uptake of tbFGF-coated POPC liposomes in cultured MEFs. MEFs were incubated with POPC liposomes presenting $0,1,5$ and $10 \%$ molar of the targeting DPTE-tbFGF to evaluate 

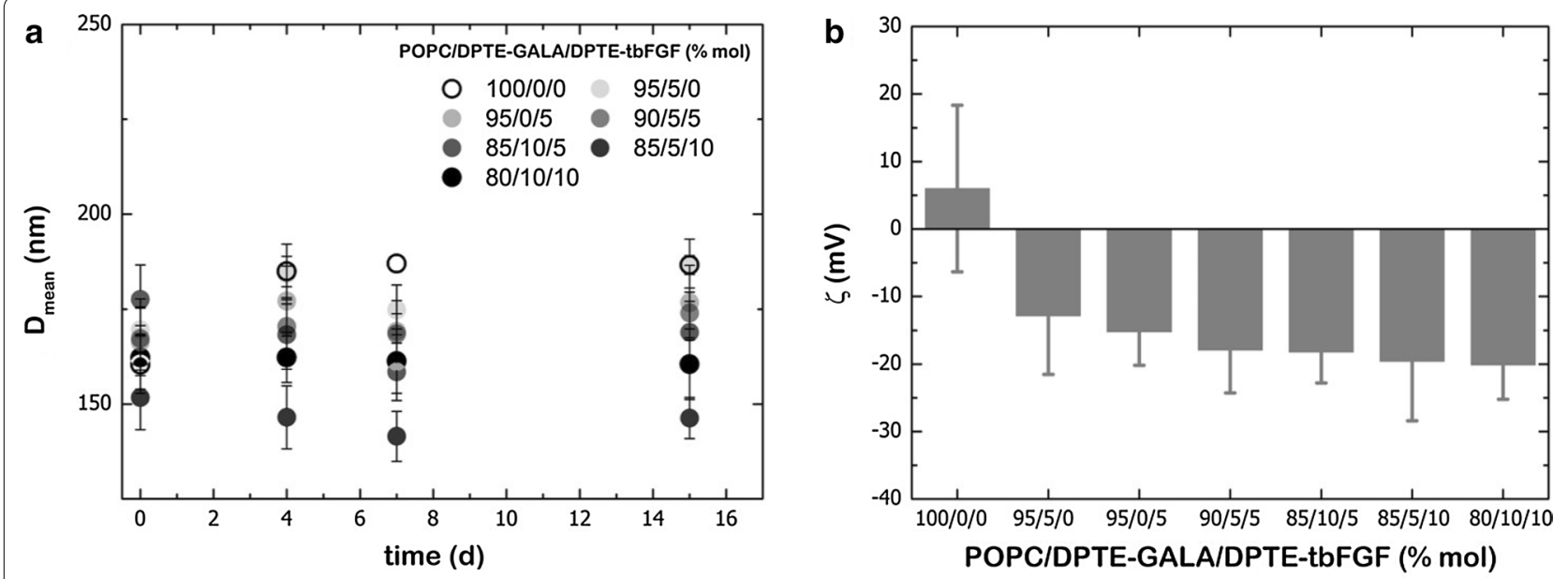

Fig. 2 a Hydrodynamic diameter of POPC/DPTE-GALA/DPTE-tbFGF liposomes at different lipo-peptide molar ratios. b Zeta potential of POPC/ DPTE-GALA/DPTE-tbFGF liposomes at different lipo-peptide molar ratios. Measurements are are representative of seven repeated experiments

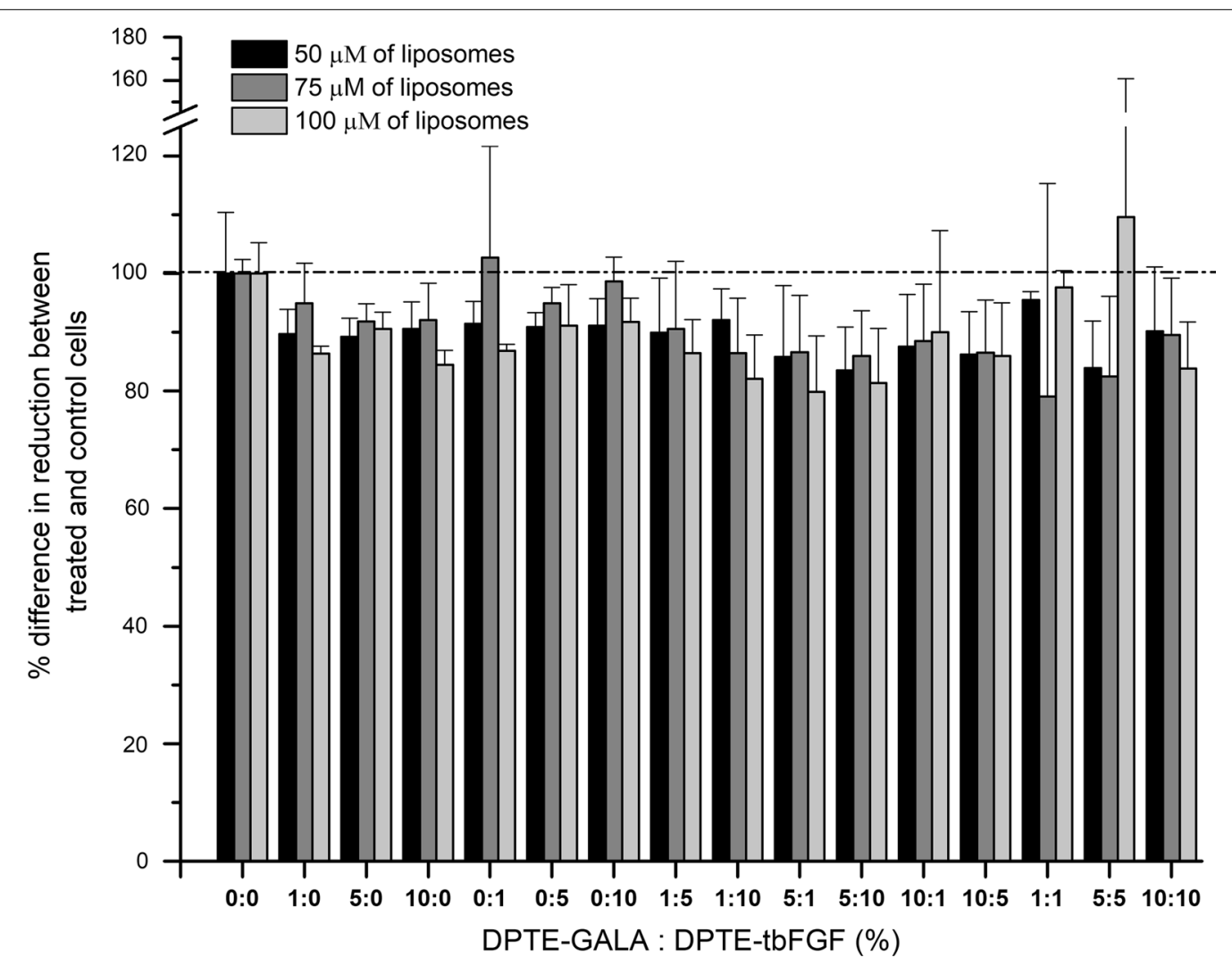

Fig. 3 Cellular viability of mouse embryonic fibroblasts exposed to POPC liposomes decorated with DPTE-tbFGF and DPTE-GALA. MEFs were exposed to 50,75 or $100 \mu \mathrm{M}$ of DPTE-tbFGF and DPTE-GALA decorated POPC liposomes for $24 \mathrm{~h}$ at $37^{\circ} \mathrm{C}$ and cell viability is assessed with the Alamar Blue reagent. The \% mol ratios of DPTE-tbFGF and DPTE-GALA on the POPC liposomes are indicated in the figure (see main text for details)

the optimal liposome formulation for a specific uptake mediated by the tbFGF. To visualize and trace liposomes inside MEFs by means of confocal fluorescence microscopy, calcein at a final concentration of $100 \mathrm{mM}$ was encapsulated in the lumen of liposomes during liposome preparation (see "Methods"). MEFs were 
imaged at 2, 4 and $6 \mathrm{~h}$ after liposome incubation. After $2 \mathrm{~h}$ of incubation (early uptake) liposome uptake can be observed for liposomes carrying 10\% of DPTE-tbFGF. A low green fluorescence signal was also observed in cells treated with lower DPTE-tbFGF concentrations (1\% or $5 \%$ ) (Fig. 4, left column). After $4 \mathrm{~h}$ of incubation, liposome uptake is observed for all formulations used (Fig. 4, central column). At $6 \mathrm{~h}$, the green level is increased for the lipid formulation carrying $10 \%$ of DPTE-tbFGF showing a high liposomal uptake. At this time point MEFs incubated with liposomes carrying $1 \%$ or $5 \%$ of DPTE-tbFGF reached comparable fluorescence intensity signals (Fig. 4, right column). For all tested conditions, control cells incubated with nondecorated bare POPC liposomes show very little, nondirected vesicle uptake, background in time (data not shown). We conclude that the presence of the DPTEtbFGF in our liposome formulation improves the specific liposome uptake of MEFs.
Endosomal escape of tbFGF- and GALA-coated liposomes To evaluate the fusogenic activity of DPTE-GALA conjugate, we first performed classical fluorescence liposome fusion assays with GALA-coated liposomes (1 and 5 molar ratios) carrying calcein at a self-quenching concentration of $100 \mathrm{mM}$ (see "Methods"). The GALA-coated liposomes were mixed with bare and non-fluorescent liposomes. Liposome fusion leads to a dilution of lumenal calcein concentration and to an increase of the calcein fluorescence signal. Signal increase is proportional to the liposome fusion activity. At pH 5.5 an increase in fluorescence signal of GALA-coated liposomes was observed indicating liposome fusion (Fig. 5a). The velocity of the observed fusion events depends on the molar amount of DPTE-GALA ( $1 \%$ or $5 \%$ ) attached to the liposome surface. At $\mathrm{pH} 8$, no calcein release was observed, neither for the presence of $1 \%$ nor $5 \%$ DPTE-GALA, whereas the addition of the detergent Triton-X100 completely solubilized the liposomes and released the total encapsulated calcein content.

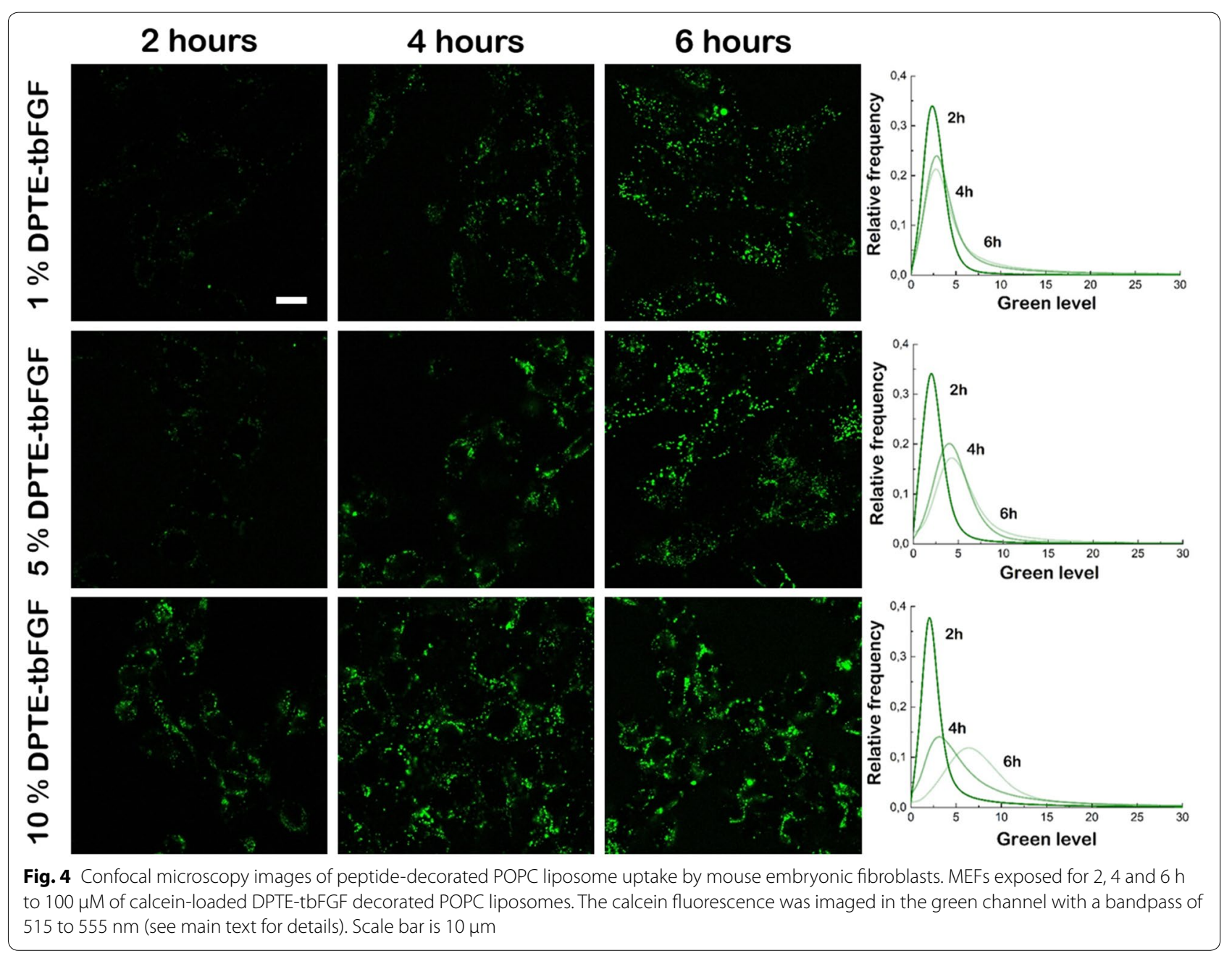




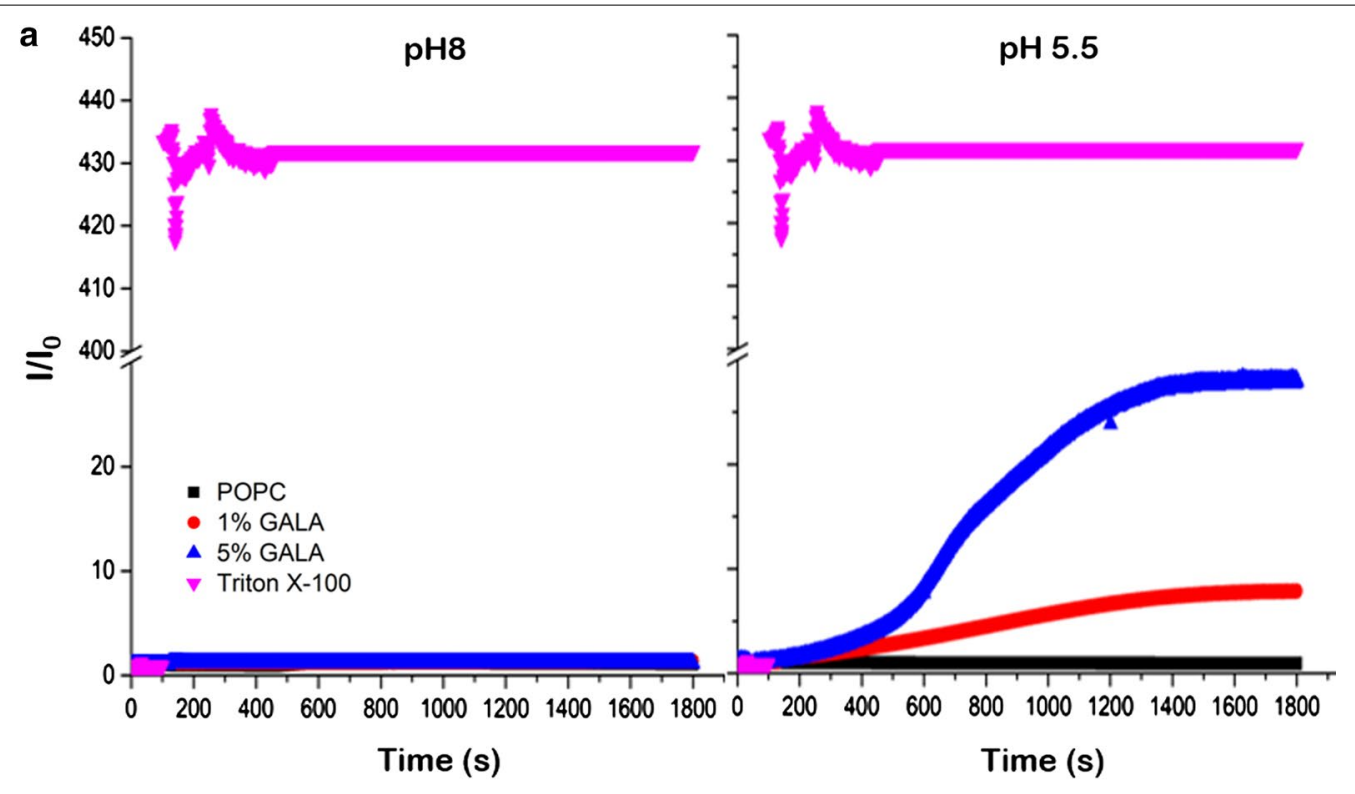

b

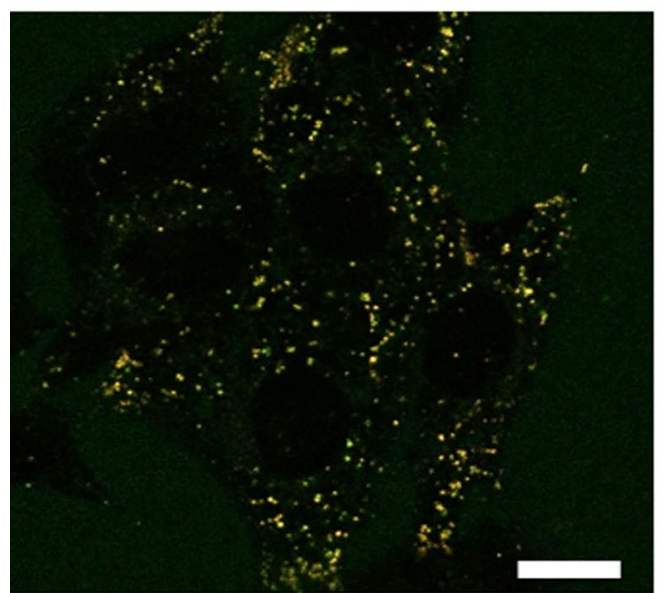

POPC/DPTE-GALA

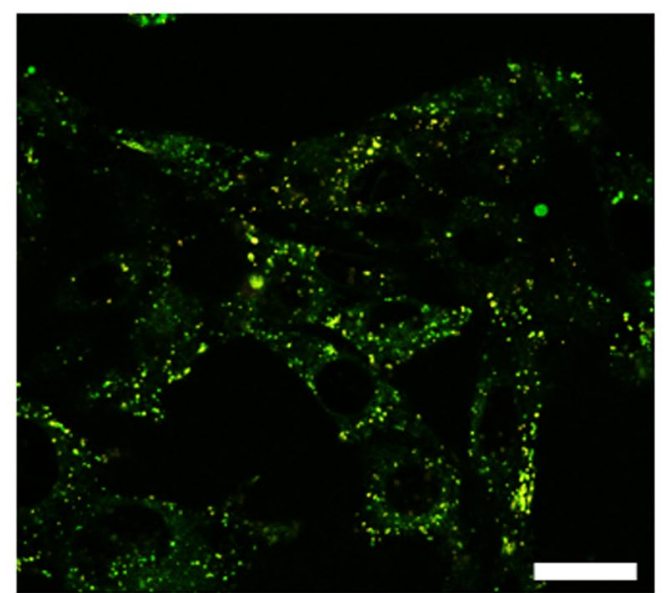

Fig. 5 Liposome fusion assay of GALA-decorated POPC liposomes. a Fusion assay of GALA-decorated POPC liposomes at pH 8 and pH 5.5 . The fusion was monitored through the change of the fluorescence intensity form encapsulated calcein at a self-quenching concentration of $100 \mathrm{mM}$. Total calcein release was monitored by the addition of Triton X-100 and non-decorated POPC liposomes were used as control. b Confocal microscopy images of MEFs exposed for $6 \mathrm{~h}$ to $100 \mu \mathrm{M}$ of calcein-loaded $10 \%$ of DPTE-GALA decorated POPC liposomes at $37^{\circ} \mathrm{C}$ stained with Lysotraker $^{\mathrm{TM}}$ RED. The Lysotraker fluorescence was imaged in the red channel. Scale bars are $10 \mu \mathrm{m}$

We then evaluated the fusogenic activity of DPTEGALA inside MEFs. To visualize and trace the calcein release inside MEFs with confocal fluorescence microscopy, the cells were incubated with Lysotracker ${ }^{\mathrm{TM}}$ Red and then incubated with $100 \mu \mathrm{M}$ POPC liposomes filled with calcein at $100 \mathrm{mM}$ and decorated with $10 \%$ mol DPTEGALA. After $12 \mathrm{~h}$, the liposome uptake is observed as the fluorescence intensity of both lysosomal and calcein channels partially colocalize. We also observe calcein fluorescence in the cytoplasm of MEFs suggesting the endosomal escape of GALA-coated liposomes from the endosomal system. For comparison, bare POPC liposomes only displayed colocalization of the green and the red fluorescence signals of the liposomes trapped in the endosomal system of the cell. We conclude that the liposome uptake in MEFs is produced via the endosomal pathway and the calcein content is released by the action of the GALA lipopeptide (Fig. 5b).

\section{Efficient ATP delivery into MEFs}

ATP is the biochemical energy of the cell and is required as many processes in cells are driven, either directly or 
indirectly, by the hydrolysis of ATP. Alteration of ATP biogenesis may cause a variety of severe mitochondrial disorders [36]. Classical pharmacological approaches that address the increase of the cellular levels of ATP are based on the stimulation of the de novo synthesis of ATP in situ [37] as the intravenous injection of ATP does not result in desired results because of the very short half-life of free blood circulating ATP [38]. Here, we test direct administration of ATP charged POPC liposomes [39] decorated with $10 \%$ mol DPTE-tbFGF and $10 \% \mathrm{~mol}$ DPTE-GALA.

MEFs were first tested for the uptake of free ATP and incubated with increasing amounts of $\operatorname{ATP}(1,2.5,5$ and $10 \mathrm{mM}$ ) and harvested after 6 and $24 \mathrm{~h}$ (see "Methods"). The ATP delivery in cultured MEFs was quantified with Luciferin/Luciferase based bioluminescence assay. Compared to untreated control cells, the results show a $20-40 \%$ increase of the cellular ATP level after $6 \mathrm{~h}$ of ATP incubation depending on the amount of ATP added to the cell culture (Fig. 6a). At $24 \mathrm{~h}$, the incubation resulted in a cellular ATP level (up to fivefold increase for $10 \mathrm{mM} \mathrm{ATP),} \mathrm{but} \mathrm{the} \mathrm{cell} \mathrm{viability} \mathrm{of} \mathrm{these} \mathrm{cells} \mathrm{was}$ severely compromised suggesting that high extracellular ATP concentrations induce cytotoxic side effects including the compromising of the cell integrity (Additional file 1: Figure S3).

After the optimization of the minimal concentration of ATP required its encapsulation into POPC liposomes carrying $10 \% \mathrm{~mol}$ of DPTE-tbFGF and $10 \% \mathrm{~mol}$ of DPTE-GALA (Additional file 1: Figure S4), MEFs were incubated for $6 \mathrm{~h}$ with POPC liposomes containing 10\% mol of DPTE-tbFGF and increasing amounts of DPTEGALA $(0,5$ and $10 \% \mathrm{~mol})$ and loaded with $50 \mathrm{mM}$ ATP. After $6 \mathrm{~h}$ of incubation, the liposomes were washed with fresh DMEM media and the intracellular ATP levels were quantified after $12 \mathrm{~h}$. Our data show that the intracellular delivery of ATP is concentration-dependent on DPTE-GALA (Fig. 6b). Again, the formulation of POPC liposomes carrying 10\% mol of DPTE-tbFGF and 10\% mol of DPTE-GALA shows an improved uptake of the ATP into the cells, reaching a maximum change of $\approx 1.5$ fold compared with untreated control cells.

\section{Protein encapsulation and release into MEFs}

To unambiguously demonstrate the delivery efficiency of tbFGF- and GALA-decorated liposomes, cell viability was verified upon incubation with liposomes encapsulating the potent $30 \mathrm{kDa}$ saporin-S6 toxin (saporin). Saporin enzymatically inactivates the ribosomes leading to a block in de novo protein synthesis, resulting in the cell death $[40,41]$. When the MEFs were exposed to 10 or $100 \mu \mathrm{g} / \mathrm{ml}$ of non-encapulated saporin, $\sim 50$ to $60 \%$ of a cell death was observed after 8 and $48 \mathrm{~h}$ of incubation respectively. However, 30 to $35 \%$ of cell death was produced when the toxin was administered in "bared" POPC liposomes. Remarkably, the presence of $10 \%$ mol DPTEGALA and DPTE-tbFGF progressively decreased the cell viability and killed $75 \%$ of the cells after $48 \mathrm{~h}$ of incubation (Fig. 7).

The cytosolic delivery of saporin was further confirmed by scanning confocal fluorescence microscopy. MEFs were labelled with the mitochondrial marker Rho123. Over time, the normal mitochondrial network of MEFs remained unaltered in the absence of treatment. In contrast, when non-encapsulated saporin was extracellularly supplemented to the medium and delivered into cells or administered through liposomes, a significant cell shrinkage and a change in mitochondrial morphology,
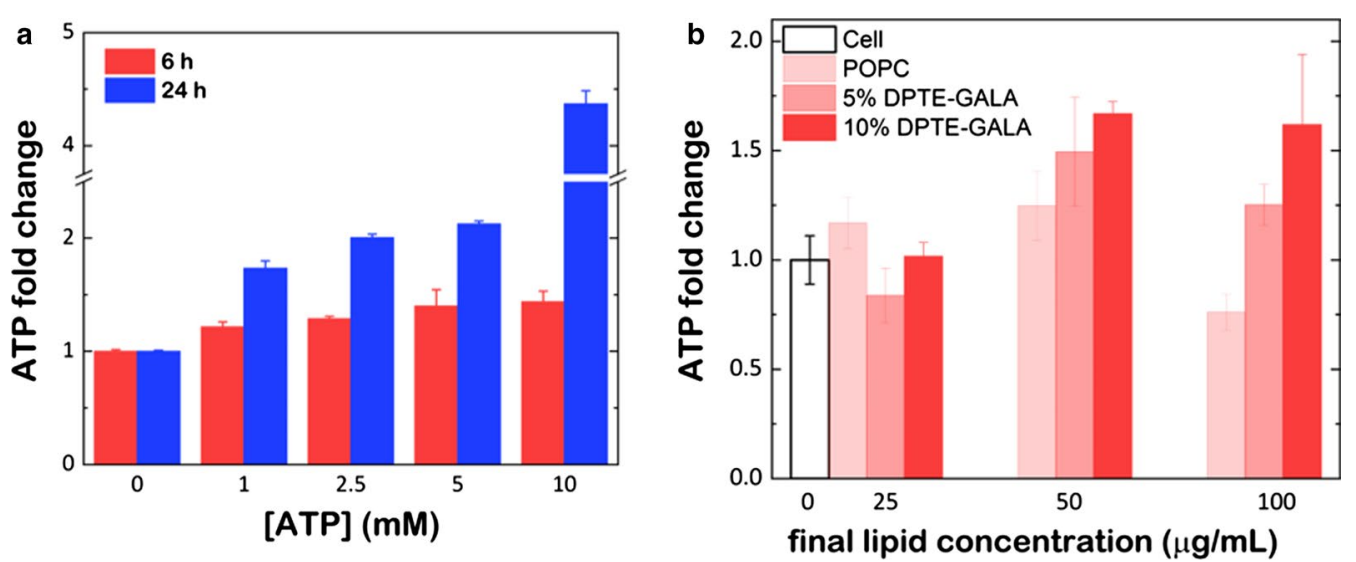

Fig. 6 ATP delivery into mouse embryonic fibroblasts. The change of the cellular ATP concentrations in MEFs upon exposure to $\mathbf{a}$ free ATP or $\mathbf{b}$ DPTE-tbFGF- and DPTE-GALA containing POPC liposomes with encapsulated ATP. In this case, MEFs were incubated for $6 \mathrm{~h}$ at $37^{\circ} \mathrm{C}$ and the cellular ATP levels were measured after $12 \mathrm{~h}$ with Luciferin/Luciferase based assay (see main text for details) 

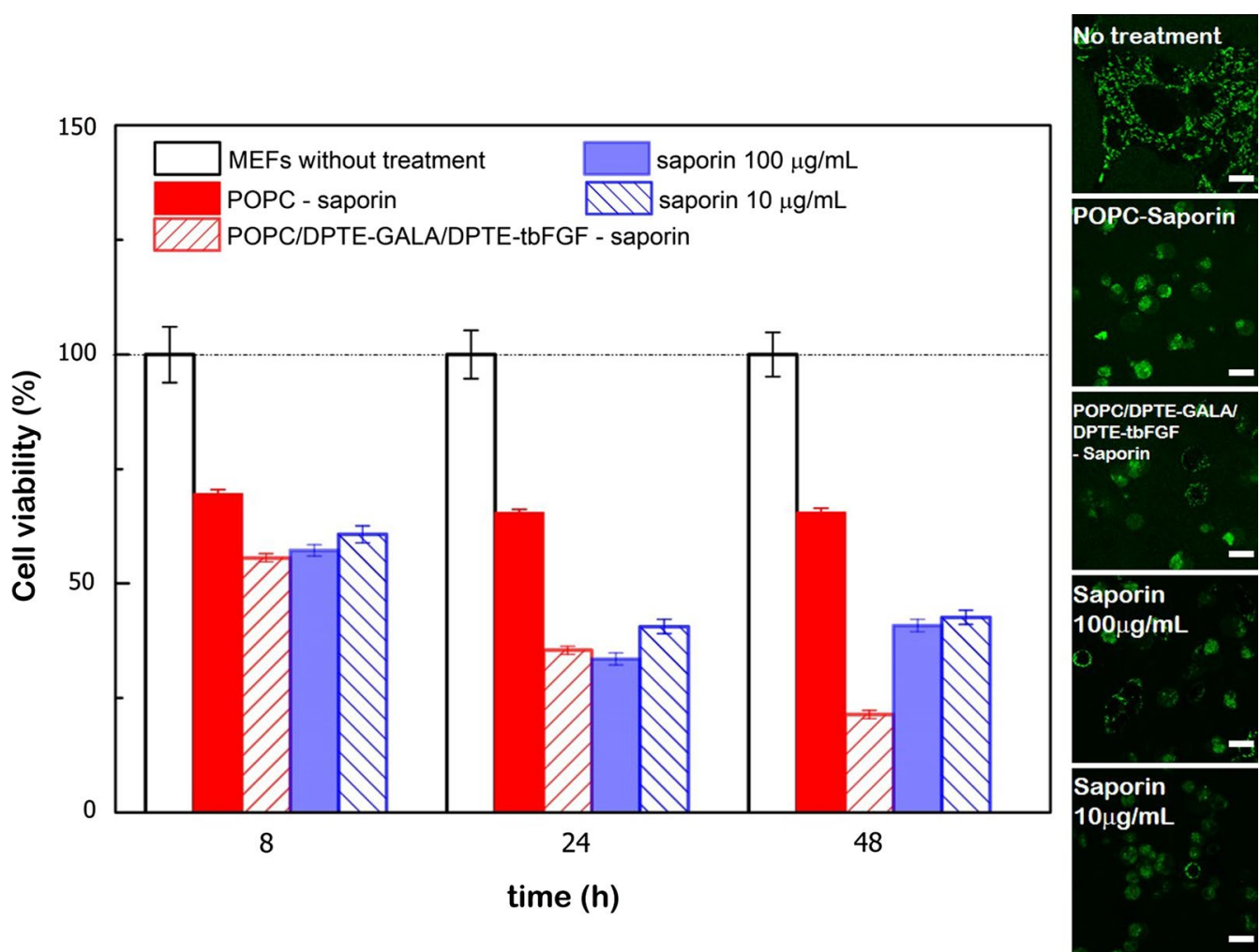

Fig. 7 Saporin toxin delivery into mouse embryonic fibroblasts. Cellular viability of MEFs as a function of time upon saporin incubation extracellularly delivered into cells or administered with liposomes decorated with DPTE-tbFGF and DPTE-GALA. (Inset) Confocal microscopy images of MEFs exposed for $24 \mathrm{~h}$ at $37^{\circ} \mathrm{C}$ to saporin $(10 \mathrm{and} 100 \mathrm{\mu g} / \mathrm{ml}$ ) and DPTE-tbFGF- and DPTE-GALA containing POPC liposomes with encapsulated saporin (nominal concentration $75 \mu \mathrm{g} / \mathrm{ml}$ ). The Rho123 fluorescence was imaged in the green channel. Scale bars are $10 \mu \mathrm{m}$

indicating cell death, was observed (inset in Fig. 7). These results collectively demonstrate that DPTE-based lipopeptides allows the delivery of proteins without the loss of functionality into the cytosol of eukaryotic cell.

\section{Discussion}

In drug delivery, the development of experimental techniques for the effective release of liposomal contents through endosomal and lysosomal membranes is key to prevent their degradation through the endosomal maturation pathway before reaching cytosolic moiety of the cell. Our finding, a peptide decorated liposome formulation, allows the specific cellular uptake and the escape of the luminal content from the endosomal system for efficient drug delivery.

In this work we used two peptides, the tbFGF and GALA to control the efficient cellular uptake and endosomal escape of our POPC liposome vector respectively. The tbFGF peptide is a truncated version of the fibroblast growth factor (FGF) that plays an important role in tumor growth and angiogenesis [42-44]. This peptide binds to the bFGF receptor but does not stimulate cell proliferation [45]. Endocytosis is the major pathway for the tbFGFp mediated cellular uptake of liposomes for cell-to-cell communication and their use in drug delivery [22, 46-51]. The GALA peptide was designed to mimic viral fusion protein sequences that interact with cell membranes to mediate the escape of the viral genes from acidic endosomes [28]. The application of the GALA peptides is well studied and used in gene transfection [52-57] and the cytosolic delivery of peptides and proteins [47]. In more detail, we conjugated DPTE to the cysteine peptides tbFGF and GALA-Cys prior to lipid vesicle preparation. The lipopeptide synthesis method (Fig. 1), based in the pyridyl disulfide reaction chemistry [21], is characterized by high yields and very easy purification procedures and differs from previously reported cysteine conjugation methods [19], which result in succinimide bonds that can be hydrolyzed spontaneously and give thus in very low coupling efficiencies. Our approach relies on the formation of a pre-conjugated nano-sized peptide-lipid system prior to their incorporation into the liposomes; whereas most of previous works dealt with some thiol-reactive polymers [58-60] or pre-formed nano-objects [21, 61, 62] that were designed to react with the cysteine residue of the targeted peptide or protein. Despite the high 
versatility of the thiopyridyl group, its reactivity depends on three main parameters: i.e. the size of the object bearing the disulfide function, the size of the molecule bearing the thiol group and the $\mathrm{pH}$ value [63]. Also, the steric hindrance of the thiol group has been found to be crucial as the kinetics of the thiol-disulfide exchange is drastically affected when a small thiol-bearing substrate was replaced by a larger one [63]. It has been also reported that the conjugation of liposomes with proteins might lead to liposome aggregation and/or a mixture of labeled and unlabeled liposomes that was difficult to resolve [64]. Our approach is thus suitable to functionalize lipids prior to liposome formation. To our knowledge, only few reports [65] follow the same strategy as ours. The advantage of our method resides on the easy modulation and control of the amount of lipopeptides to be incorporated into the liposomes.

Moreover, DPTE is commercially available and provides a stable membrane anchoring of peptides to the lipid bilayer in comparison with single fatty acid chain derivatives. The resulting lipopeptides are soluble in organic solvents such as methanol or chloroform and can be incorporated into liposomes in the same manner as common phospholipids. This allows the controlled surface decoration and the controlled mixing of different peptides on the liposome surface without loss of peptide functionally and ensures the peptide anchoring to the lipid bilayer without impairing the stability and size of liposomes (Fig. 2a). In particular, we demonstrate the $\mathrm{pH}$-dependent fusogenic properties of liposomes containing DPTE-GALA in a physiologically relevant pH-range (Fig. 5a). The liposomes can fuse with stable target liposomes with a size that mimics the endosomal vesicles in cells. The lipopeptide DPTE-GALA presents similar characteristics of GALA lipopeptides previously described in the literature, where two myristoyl chains were attached to the end of GALA through 1,2-diamino propanoic acid, yielding the lipopeptide DMDGALA [66]. The pH-dependent fusion of DPTE-GALA containing liposomes allows them to be used for drug delivery applications. To this end, the effects of adding the targeting lipopeptide DPTE-tbFGF to the liposome surface was investigated. The combined addition of different DPTEbased lipopeptides (up to $20 \% \mathrm{~mol}$ of liposome composition) might compromise cell viability. However, we have found that the action of both DPTE-peptides are biocompatible and does not produce cytotoxicity (Fig. 3).

To establish the optimal formulation for efficient cellular uptake and drug release, MEFs were exposed to POPC liposomes decorated with 0 to $10 \%$ of DPTE-tbFGF and/ or DPTE-GALA and incubated for $6 \mathrm{~h}$ at $37{ }^{\circ} \mathrm{C}$. Confocal microscopy imaging shows the effective cellular uptake of calcein-loaded liposomes and the cytosolic release of its content. An enhanced uptake is observed with increasing amounts of DPTE-tbFGF (Fig. 4) and no significant cytosolic spread of calcein was observed in the absence of DPTE-GALA (Fig. 5). These observations strongly suggest the involvement of endocytosis in the cellular uptake. Additional experiments inhibiting the cellular uptake are required to quantitatively ascertain the importance of endosomal pathway and ulterior acidification in this targeting system. At low temperature $\left(4{ }^{\circ} \mathrm{C}\right)$ the energy-driven processes including endocytosis are suppressed and the presence of ammonium chloride, prevents endosomal acidification [67]. Nonetheless, liposomes attaching GALA are proficient for membrane disruption at low $\mathrm{pH}$ in living cells. This was previously shown in vitro for GALA attached to a flat gold surface [68]. In our case, an increase in DPTE-GALA in the presence of $10 \%$ mol DPTE-tbFGF, led to a faster cytosolic delivery of calcein, however we did not quantify the efficiency of the delivery. No significant cytotoxicity was observed during these incubations even when both, DPTE-tbFGF and DPTE-GALA were present up to $10 \%$ mol. However, a larger excess of both DPTE-GALA and DPTE-tbFGF does not necessarily yield to an increased and more efficient cytosolic drug release. The excess of DPTE-GALA might even increase the negative charges on the liposomal surface (Fig. 2b) and interfere with specific DPTE-tbFGF mediated cellular uptake [57]. We did not investigate the fate of the liposome components after drug delivery, but expect them to be degraded and completely cleared from the cells [69].

For a supplementary piece of evidence of quantitative delivery, we loaded liposomes with ATP and monitor the cellular ATP levels. After incubation with peptide-coated liposomes, we were able to increase the ATP levels in MEFs (Fig. 6). The addition of extracellular (non-capsulated) ATP to cell cultures is known to be toxic at high concentrations [70], thus encapsulation might allow efficient cytosolic delivery of ATP without the need of de novo synthesis. The presence of both tbFGF as well as the GALA is essential for the efficient cytoplasmic release of ATP. This preliminary data indicates that our formulation might be a favorable combination needed for efficient cytosolic targeting and release. However, the ATP quantification is carried out after cell lysis and therefore the endosomal contents might be released during manipulation and the quantification biased. A concluding demonstration of the delivery efficiency of tbFGF- and GALA-coated liposomes came from the encapsulation and the release of saporin toxin that blocks the de novo protein synthesis by inactivating the ribosomes in the cytosol. Our results (Fig. 7) demonstrate an enhanced cytotoxicity when the toxin was delivered through liposomes enriched in DPTE-GALA and DPTE-tbFGF as 
compared to controls. In contrast to a single dose of high concentrated saporin, the combined action of lipopetides might mediate a progressive release of the saporin toxin producing a gradual enhanced cytotoxicity that might counterbalance the gradual cell recovery eventually leading to a higher cell death (Fig. 7).

Overall, the optimal combination of POPC liposomes enriched with DPTE-GALA and DPTE-tbFGF (molar ratios of 8:1:1) was important to attain an effective balance of internalization and cytosolic release and was found to be biocompatible in mouse embryonic fibroblasts. The success of our liposome formulation can be attributed to the presence of DPTE, a thiol-containing lipid that can efficiently be incorporated into biological membranes [71, 72].

\section{Conclusion}

We used a straightforward methodology for the formulation of peptide-decorated liposomes to ensure the efficient enhanced cellular uptake and cytosolic release of encapsulated cargo. The targeted peptide tbFGF and the pH-sensitive fusogenic peptide GALA were conjugated via cysteine residue to the thiol-containing phospholipid DPTE prior to vesicle preparation. Although further studies are needed for more advanced and fine-tuned control of the cellular uptake and cytosolic release inside live cells, our formulation strategy will greatly contribute to the application of drug delivery to assess therapeutic remedies to cells with pathological phenotypes.

\section{Methods}

\section{Lipids, fluorescent probes, peptides and toxin}

1-Palmitoyl-2-oleoyl-sn-glycero-3-phosphocholine (POPC), and 1,2-dipalmitoyl-sn-glycero-3-phosphothioethanol (DPTE) were supplied by Avanti Polar Lipids. The peptides NH2-KRTGQYKLC-COOH and NH2WEAA-LAEA-LAEA-LAE-H-LAEA-LAEA-LEALAAC$\mathrm{COOH}$ were synthesized by GenScript (Piscataway, NJ USA) and used without any further purification step. Lysotraker $^{\mathrm{TM}}$ RED (L7528) was purchased form Thermofisher. Saporin (S9896), calcein (21030, Fluka) and Rhodamine 123 (R8004) were purchased from Sigma Aldrich.

\section{Conjugation of the cysteine-containing peptides with the lipid}

\section{1,2-dipalmitoyl-sn-glycero-3-phospho-thio-ethanol}

The conjugated lipopeptides were synthetized in two steps. The first step consists on the activation of the thiol group of the lipid 1,2-dipalmitoyl-sn-glycero-3-phosphothioethanol (DPTE; Avanti Lipids) and the second step is the conjugation of the reactive dissymmetric disulfide DPTE (aDPTE) with the cysteine residue of the tbFGF and GALA-Cys peptides (GenScript, Piscataway, NJ USA). In more detail, $200 \mathrm{mg}(275 \mu \mathrm{mol})$ of DPTE and $120 \mathrm{mg}(550 \mu \mathrm{mol})$ of 2,2'-dipyridyldisulfide (DPDS) were first dissolved in methanol:acetic acid (MeOH:AcOH $160: 1, \mathrm{v} / \mathrm{v}$ ), in a final volume of $4 \mathrm{ml}$ and incubated under stirring for $48 \mathrm{~h}$ at RT in the dark. For the second reaction, $5 \mathrm{mg}(6 \mu \mathrm{mol})$ of aDPTE was incubated with $40 \mathrm{mg}$ $(40 \mu \mathrm{mol})$ of tbFGF or $120 \mathrm{mg}(40 \mu \mathrm{mol})$ of GALA-Cys (1:7 mol:mol aDPTE:peptide ratio) in a mixture of tetrahydrofuran (THF) and $1 \mathrm{M}$ Tris $\mathrm{HCl} \mathrm{pH} 9$ (2:1; vol:vol) in a final volume of $3 \mathrm{ml}$ and stirred for $48 \mathrm{~h}$ at $20^{\circ} \mathrm{C}$ in the dark. The release of mercaptopyridine in both reactions was monitored spectrophotometrically (Genesis 10 spectrophotometer; Fisher Scientific) at $362 \mathrm{~nm}$. The absorption spectra of the reaction mixture were recorded during incubation at $20{ }^{\circ} \mathrm{C}$ in disposable cuvettes with an optical path of $1 \mathrm{~cm}$ from $300 \mathrm{~nm}$ to $500 \mathrm{~nm}$ with a spectral resolution of $1.0 \mathrm{~nm}$ and a scan rate of $200 \mathrm{~nm} /$ min. The reaction takes place within the first $10 \mathrm{~min}$ where mercaptopyridine is released very fast, but is left up to $48 \mathrm{~h}$ to ensure complete reaction of the substrates. During the synthesis, samples were analyzed by thin layer chromatography by comparing the $\mathrm{R}_{f}$ values of reaction products with protein and lipid standards.

\section{Thin layer chromatography}

Preparative silica TLC [73] was used to remove mercaptopyridine from conjugation reaction using acetone as the mobile phase. The mercaptopyridine runs in the acetone front leaving both, the aDPTE and the DPTEpeptide, behind on the silica plate. Both the aDPTE and DPTE-peptide were scraped from the preparative TLC plate (Analtech, USA) and dissolved in $30 \mathrm{ml}$ of chloroform and applied on a silica column for further purification.

\section{Column preparation and elution}

Silica Gel (Sigma-Aldrich), suspended in chloroform, was packed to a height of $30 \mathrm{~cm}$ column. Applying slight air pressure during packing resulted in a uniform distribution of adsorbent, which was supported and covered by small glass wool plugs. The scraped lipid-silica mixture was suspended in chloroform and applied to the prepacked column and washed with three column volumes of chloroform:methanol mixture $\left(\mathrm{CHCl}_{3}: \mathrm{MeOH} ; 9: 1: \mathrm{v} / \mathrm{v}\right)$ to elute the lipid mixture into the column. The DPTE and DPTE-peptide will dissolve in the mobile phase whereas the silica will remain packed on the prepacked solid silica phase. Elution was carried out with three column volumes of $\mathrm{CHCl}_{3}: \mathrm{MeOH}(13: 5 ; \mathrm{v} / \mathrm{v})$ at room temperature under slight air pressure. The eluate was collected in $30 \mathrm{ml}$ fractions and analyzed by TLC to detect the presence of DPTE or DPTE-peptide. Lipids were visualized 
with the molybdic oxide-molybdenum "Zinzadze" phosphorus staining reagent [74]. The fractions containing the aDPTE or DPTE-peptide were pooled individually, the solvents evaporated under nitrogen and the residual lipids or conjugates stored at $-20{ }^{\circ} \mathrm{C}$ until further use. The lipid and protein content of the obtained products were determined according to Rouser [33] and Lowry [34] respectively to calculate the efficiency of synthesis. The synthesized products (aDPTE and DPTE-peptide) were characterized by $1 \mathrm{H}$ NMR spectroscopy (NMR CAI; Universidad Complutense Madrid).

\section{Preparation of liposomes}

Liposomes were prepared according to the standard thin-film hydration method [75]. For the different formulations used here, the lipid and DPTE-peptide containing chloroform solutions were mixed and dried using a vacuum concentrator (Eppendorf). Dried films were then hydrated with $500 \mu \mathrm{l}$ of in $\mathrm{Ca}^{2+}$ and $\mathrm{Mg}^{2+}$ free PBS (the final lipid concentration was $1 \mathrm{mg} / \mathrm{ml}$ ) and vortexed for 10 min facilitating hydration of the lipids and the formation or multilamellar lipid vesicles (MLVs). After hydration the sample was extruded through a polycarbonate membrane (100 nm pore size; Avanti lipids) and exposed to MEFs grown in DMEM (see "Cell cultures") for viability, uptake and release assays. For confocal experiments, calcein $(100 \mathrm{mM})$ was added to buffer prior to rehydration step. Calcein containing MLVs were dispersed by vortexing (5 $\mathrm{min})$ and sonication of the turbid suspension up to $20 \mathrm{~min}$. Liposomes were washed trice with $40 \mathrm{mM}$ HEPES by ultracentrifugation (Beckmann, TLA120 rotor, $100,000 \times g, 60 \mathrm{~min}$ ) and resuspended in a final volume of $500 \mu \mathrm{l}$ of $50 \mathrm{mM}$ HEPES, $150 \mathrm{mM} \mathrm{KCl}$, pH 8 for lipid-mixing assays or $\mathrm{Ca}^{2+}$ and $\mathrm{Mg}^{2+}$ free PBS for cell assays. For ATP and saporin delivery experiments, the lipid film was rehydrated in the presence of $0 \mathrm{mM}$ (control), $10 \mathrm{mM}, 25 \mathrm{mM} 50 \mathrm{mM}$ and $100 \mathrm{mM}$ of ATP buffered in $1 \mathrm{M}$ HEPES pH 7.2 or $75 \mu \mathrm{g} / \mathrm{ml}$ of saporin buffered in $100 \mathrm{mM}$ HEPES $\mathrm{pH}$ 7.2. ATP or saporin containing MLVs were dispersed by vortexing $(5 \mathrm{~min})$ and sonicated up to $20 \mathrm{~min}$ until they became transparent. Liposomes were washed trice with $1 \mathrm{M}$ HEPES pH 7.2 or in $100 \mathrm{mM}$ HEPES pH 7.2 by ultracentrifugation (Beckmann, TLA120 rotor, $100,000 \times g, 60 \mathrm{~min}$ ) and resuspended in a final volume of $100 \mu \mathrm{l}$ of 1 M HEPES pH 7.2 or in $100 \mathrm{mM}$ HEPES pH 7.2 at a final lipid concentration of $1 \mathrm{mg} / \mathrm{ml}$. The final concentration upon incubation with MEFs was achieved after further dilution in DMEM media.

\section{Chemical analysis, DLS and zeta potential of liposomes}

The lipid and lipopeptide content of liposomes before and after extrusion were also determined according to
Rouser [33] and Lowry [34]. The diameters and the zetapotential of the liposomes were measured as a function of the molar ratio of lipopeptides by dynamic light scattering (DLS) and electrophoretic mobility measurements in a 90 Plus Particle Analyzer (Brookhaven Instruments).

\section{Liposomes fusion assay}

$15 \mathrm{mM}$ POPC/DPTE-GALA liposomes carrying increasing amount of DPTE-GALA (1,5\% mol) loaded with calcein at self-quenching concentration of $100 \mathrm{mM}$ were incubated with empty $15 \mathrm{mM}$ POPC liposomes (1:9 vol:vol) and titrated with $0.1 \mathrm{M} \mathrm{HCl}$ to drop the external $\mathrm{pH}$ from 8 to 5.5. The fusion assay is based on the dilution of the lumenal calcein concentration that leads to an increase of the fluorescence signal. The fluorescence signal was monitored spectroscopically on an AMINCOBowman Series 2 (AB2) Spectrofluorometer (emission wavelength of $520 \mathrm{~nm}$ upon excitation at $495 \mathrm{~nm}$ and slit width of $5 \mathrm{~nm}$ ). The maximal calcein release of the POPC-DPTE-GALA liposomes was estimated after solubilization of $1 \%$ of triton $\mathrm{X}-100$ at $\mathrm{pH} 8$ and 5.5 .

\section{Cell culture}

The mouse embryonic fibroblasts (MEF; purchased from ATCC) were cultured in complete DMEM (high glucose Dulbecco Modified Eagle Medium), $25 \mathrm{mM}$ Glucose (Gibco) supplemented with 10\% fetal bovine serum (South Africa S1300; Biowest, Nuallé, France), penicillin/ streptomycin (final concentration $100 \mathrm{U} / \mathrm{ml}$ of penicillin and $100 \mu \mathrm{g} / \mathrm{ml}$ of streptomycin respectively) and $1 \%$ of non-essential amino acids (all Gibco). The cells were grown in a humidified incubator (Forma Steri-Cycle Themofisher; $5 \% \mathrm{CO}_{2}$ ) at $37{ }^{\circ} \mathrm{C}$ and maintained, with split ratio of 1:20, at $80 \%$ of confluence in T75 flasks (Nunc).

\section{Cell viability assays}

The cell viability of treated MEFs was monitored with the Alamar Blue viability assay (Serotec, Oxon, UK) [76-78] according to manufacturer's instructions. This cell viability assay is based on a reazurin that reflects the redox state of the cell. In living cells, reazurin (7-Hydroxy$3 \mathrm{H}$-phenoxazin-3-one 10-oxide) is effectively reduced due to mitochondrial metabolic activity, where NADPH or NADH reduces the blue resazurin to the red resorufin [79]. Reazurin absorption was measured at $570 \mathrm{~nm}$ and data was corrected according to:

$$
\frac{\left(\varepsilon_{o x}\right) \lambda_{2} \mathrm{~A} \lambda_{1}-\left(\varepsilon_{o x}\right) \lambda_{1} \mathrm{~A} \lambda_{2}}{\left(\varepsilon_{o x}\right) \lambda_{2} \mathrm{~A}^{o} \lambda_{1}-\left(\varepsilon_{o x}\right) \lambda_{1} \mathrm{~A}^{o} \lambda_{2}} \times 100
$$

with $\lambda_{1}=570 \mathrm{~nm}$ and $\lambda_{2}=620 \mathrm{~nm}, \varepsilon_{\mathrm{ox}}=80,586 \mathrm{~L} \mathrm{~mol}^{-1}$ $\mathrm{cm}^{-1}$ at $570 \mathrm{~nm}, \mathrm{~A} \lambda_{1}$ the absorption at $570 \mathrm{~nm}$ and $\mathrm{A} \lambda_{2}$ the absorption at $620 \mathrm{~nm}$, the superscript ${ }^{\circ}$ stands for the positive control well. MEFs were lifted and seeded in 
96-well plates at a density of $3 \times 10^{3}$ cells $/ \mathrm{cm}^{2}$. After $24 \mathrm{~h}$ of incubation at $37{ }^{\circ} \mathrm{C}$ with $5 \% \mathrm{CO}_{2}$ and $95 \%$ humidity in the cell incubator to allow cell attachment, $10 \mu \mathrm{l}$ of the Alamar Blue reagent is added to each well of the 96-well plate and incubated for additional $2 \mathrm{~h}$ at $37{ }^{\circ} \mathrm{C}$ with $5 \%$ $\mathrm{CO}_{2}$ and $95 \%$ humidity in the cell incubator. After incubation, absorption of individual plate was measured at $570 \mathrm{~nm}$ and $620 \mathrm{~nm}$ in a Multiskan ${ }^{\mathrm{TM}}$ FC (Thermo Scientific $^{\mathrm{TM}}$ ) plate reader. Data was analyzed with a two-way ANOVA (p-value $<0.05$ ) relating cell death to the ratios of DPTE-GALA/DPTE-tbFGF and the total concentration of transfected liposomes $(50,75$ and $100 \mu \mathrm{M})$ or ATP concentration.

\section{Confocal laser scanning microscopy}

Confocal laser scanning microscopy images were taken of MEFs seeded in a four-chamber LabTeck ${ }^{\circledR}$ (C6807, Sigma-Aldrich) at a density of $1 \times 10^{5}$ cells per $\mathrm{cm}^{2}$ in complete DMEM and incubated for $24 \mathrm{~h}$ at $37{ }^{\circ} \mathrm{C}$. Before microscopy MEFs were washed twice with HBBS and incubated in complete DMEM medium containing $100 \mu \mathrm{M}$ of liposomes. Cells were imaged at 2, 4 and/or $6 \mathrm{~h}$ after liposome incubation. The LabTeck ${ }^{\circledR}$ chamber was mounted on a stage of a Nikon Ti-E inverted microscope at $37{ }^{\circ} \mathrm{C}$ equipped with a Nikon $\mathrm{C} 2$ confocal spot microscope, Nikon Plan Apo 100× NA oil immersion objective $1.45 \mathrm{UV}$ filter cubes-2E/C (excitation band 340-380 nm, emission band 435-485 nm), B-2E/C (excitation band: $465-495 \mathrm{~nm}$, emission band: $515-555 \mathrm{~nm}$ and Y-2E/C (excitation band: $540-580 \mathrm{~nm}$, emission band: $600-660 \mathrm{~nm})$. Images were captured with Nikon NIS-Elements software and processed with ImageJ software package [80].

\section{Luciferase assay}

Intracellular ATP and encapsulated ATP in the liposome were quantified using ATP Determination Kit (Thermo Fisher Scientific, USA) and performed according to manufacturer instructions. For ATP or ATP encapsulated liposome treatment, MEFs were grown on 96-well plate by seeding $1.5 \times 10^{4}$ cells/well. After $24 \mathrm{~h}$ of incubation at $37{ }^{\circ} \mathrm{C}$ with $5 \% \mathrm{CO}_{2}$ and $95 \%$ humidity in the cell incubator each well was treated with $100 \mu \mathrm{l}$ of DMEM with appropriate concentration of ATP or liposome and measured the intracellular ATP at different time points. For quantification of ATP, the cells were washed three times with PBS to remove the unbound ATP. Thereafter $100 \mu \mathrm{l}$ lysis buffer $(0.2 \mathrm{M}$ borate buffer, $0.1 \%$ Triton $\mathrm{X} 100, \mathrm{pH}$ 9.2) was added to each well and the plates were kept at room temperature for $10 \mathrm{~min}$. The resultant lysate was further diluted with $200 \mu \mathrm{l}$ lysis buffer then transferred to a $1.5 \mathrm{ml}$ eppendorf tube. The cellular debris were removed by centrifugation at $13,500 \times g$ and $4{ }^{\circ} \mathrm{C}$ for
$10 \mathrm{~min}$ and supernatant were transferred to new eppendorf tube. $10 \mu \mathrm{l}$ of the supernatant was used for ATP determination assay. To determine the encapsulated ATP in the liposome, $50 \mu \mathrm{l}$ liposomes were lysed using $50 \mu \mathrm{l}$ lysis buffer as mentioned above, incubated for $10 \mathrm{~min}$ and then diluted three-fold by the addition of $200 \mu \mathrm{l}$ lysis buffer. $10 \mu$ of lysate was used to determine the ATP concentration. Luminescence assay was performed with a white 96-well plate and luminescence was measured with a microplate reader at $560 \mathrm{~nm}$ (BMG Labtech, Germany).

\section{Additional file}

Additional file 1. Additional figures and table.

\section{Abbreviations}

1H-NMR: nuclear magnetic resonance; aDPTE: activated 1,2-dipalmitoyl-snglycero-3-phosphothioethanol; bFGF: basic fibroblast growth factor; tbFGF: truncated basic fibroblast growth factor; DMEM: Dulbecco's modified Eagle Medium; DPDS: 2-2-pyridyl disulfide; DPTE: 1,2-dipalmitoyl-sn-glycero3-phosphothioethanol; GALA peptide: 30 amino acid synthetic peptide with glutamic acid-alanine-leucine-alanine (EALA) repeat; GALA-Cys: GALA peptide with C-terminal cysteine residue; HBBS: Hank's buffered salt solution; MEF: mouse embryonic fibroblasts; PBS: phosphate buffered saline.

\section{Acknowledgements}

The authors wish to thank Pr. Francisco Javier Turnay Abad (Dto. Bioquímica y Biología Molecular, Universidad Complutense de Madrid) for microplate luminiscence measurements. AKM thanks the Korea EU-ERC researcher exchange program funded by National Research Foundation (NRF), South Korea (Grant No-2017R1C1B1003495). MMU was recipient of a Sara Borrell fellowship (CD15/00190) financed by the Spanish Ministry of Health.

\section{Authors' contributions}

IL-M conceived and designed the experiments. DF-H, AKM, MM-U, EE, AM-P and IL-M performed the experiments. DF-H, AKM, PN and IL-M analyzed the data. AKM, PN, FG, LS and IL-M drafted and wrote the manuscript. All authors read and approved the final manuscript.

\section{Funding}

This work was financial supported by the European Research Council (ERCStG-338133, mitochon).

\section{Availability of data and materials}

All data generated or analyzed during this study are included in this published article.

Ethics approval and consent to participate

Not applicable.

\section{Consent for publication}

All authors have provided consent for the manuscript to be published.

\section{Competing interests}

The authors declare that they have no competing interests.

\footnotetext{
Author details

${ }^{1}$ Dto. Química Física, Universidad Complutense de Madrid, Avenida Complutense s/n, 28040 Madrid, Spain. ${ }^{2}$ Instituto de Investigación Hospital Doce de Octubre (i+12), Avenida de Córdoba s/n, 28041 Madrid, Spain. ${ }^{3}$ Department of Biological Sciences, School of Life Sciences, Ulsan National Institute of Science and Technology (UNIST), Ulsan 689-798, Republic of Korea.

${ }^{4}$ Dto. Química Orgánica, Universidad Complutense de Madrid, Avenida Complutense s/n, 28040 Madrid, Spain. ${ }^{5}$ Institut de Chimie Séparative de
} 
Marcoule, ICSM, UMR 5257, Site de Marcoule-Bât, 426 BP 17 171, 30207 Bagnols sur Ceze, France.

Received: 9 April 2019 Accepted: 10 June 2019

Published online: 21 June 2019

\section{References}

1. Sercombe L, Veerati T, Moheimani F, Wu SY, Sood AK, Hua S. Advances and challenges of liposome assisted drug delivery. Front Pharmacol. 2015;6:286.

2. Zola H. Detection of receptors for cytokines and growth factors. Immunologist. 1994;2:47-50.

3. van Meer G, de Kroon AIPM. Lipid map of the mammalian cell. J Cell Sci. 2011:124:5-8

4. Mouritsen OG. Lipids, curvature, and nano-medicine. Eur J Lipid Sci Technol. 2011:113:1174-87.

5. Mell M, Moleiro LH, Hertle Y, Fouquet P, Schweins R, Lopez-Montero I, Hellweg T, Monroy F. Bending stiffness of biological membranes: what can be measured by neutron spin echo? Eur Phys J E Soft Matter. 2013;36:75.

6. Catapano ER, Arriaga LR, Espinosa G, Monroy F, Langevin D, LopezMontero I. Solid character of membrane ceramides: a surface rheology study of their mixtures with sphingomyelin. Biophys J. 2011;101:2721-30.

7. Espinosa G, López-Montero I, Monroy F, Langevin D. Shear rheology of lipid monolayers and insights on membrane fluidity. Proc Natl Acad Sci. 2011:108:6008-13.

8. Yudina A, de Smet M, Lepetit-Coiffe M, Langereis S, Van Ruijssevelt L, Smirnov P, Bouchaud V, Voisin P, Grull H, Moonen CT. Ultrasound-mediated intracellular drug delivery using microbubbles and temperaturesensitive liposomes. J Control Release. 2011;155:442-8.

9. Bibi S, Lattmann E, Mohammed AR, Perrie Y. Trigger release liposome systems: local and remote controlled delivery? J Microencapsul. 2012;29:262-76.

10. Zola H, Flego L, Sheldon A. Detection of cytokine receptors by highsensitivity immunofluorescence/flow cytometry. Immunobiology. 1992;185:350-65.

11. Ashley CE, Carnes EC, Phillips GK, Padilla D, Durfee PN, Brown PA, Hanna TN, Liu J, Phillips B, Carter MB, et al. The targeted delivery of multicomponent cargos to cancer cells by nanoporous particle-supported lipid bilayers. Nat Mater. 2011:10:389-97.

12. Ahijado-Guzmán R, González-Rubio G, Izquierdo JG, Bañares L, LópezMontero I, Calzado-Martín A, Calleja M, Tardajos G, Guerrero-Martínez A. Intracellular pH-induced tip-to-tip assembly of gold nanorods for enhanced plasmonic photothermal therapy. ACS Omega. 2016;1:388-95.

13. Landfester K, Mailander V. Nanocapsules with specific targeting and release properties using miniemulsion polymerization. Expert Opin Drug Deliv. 2013;10:593-609.

14. Narayanan K, Yen SK, Dou Q, Padmanabhan P, Sudhaharan T, Ahmed S, Ying JY, Selvan ST. Mimicking cellular transport mechanism in stem cells through endosomal escape of new peptide-coated quantum dots. Sci Rep. 2013:3:2184.

15. Kono K, Igawa T, Takagishi T. Cytoplasmic delivery of calcein mediated by liposomes modified with a $\mathrm{pH}$-sensitive poly(ethylene glycol) derivative. Biochimica Et Biophysica Acta-Biomembranes. 1997;1325:143-54.

16. Wong ASM, Mann SK, Czuba E, Sahut A, Liu HY, Suekama TC, Bickerton T, Johnston APR, Such GK. Self-assembling dual component nanoparticles with endosomal escape capability. Soft Matter. 2015;11:2993-3002.

17. Zhang DD, Wang JX, Xu DG. Cell-penetrating peptides as noninvasive transmembrane vectors for the development of novel multifunctional drug-delivery systems. J Control Release. 2016;229:130-9.

18. Nair DP, Podgórski M, Chatani S, Gong T, Xi W, Fenoli CR, Bowman CN. The thiol-michael addition click reaction: a powerful and widely used tool in materials chemistry. Chem Mater. 2014;26:724-44.

19. Kalia J, Raines RT. Advances in bioconjugation. Curr Org Chem. 2010;14:138-47.

20. Arunachalam B, Phan UT, Geuze HJ, Cresswell P. Enzymatic reduction of disulfide bonds in lysosomes: characterization of a gamma-interferoninducible lysosomal thiol reductase (GILT). Proc Natl Acad Sci USA. 2000;97:745-50.
21. van der Vlies AJ, O'Neil CP, Hasegawa U, Hammond N, Hubbell JA. Synthesis of pyridyl disulfide-functionalized nanoparticles for conjugating thiol-containing small molecules, peptides, and proteins. Bioconjug Chem. 2010;21:653-62.

22. Terada T, Mizobata M, Kawakami S, Yabe Y, Yamashita F, Hashida M. Basic fibroblast growth factor-binding peptide as a novel targeting ligand of drug carrier to tumor cells. J Drug Target. 2006;14:536-45.

23. Yayon A, Aviezer D, Safran M, Gross JL, Heldman Y, Cabilly S, Givol D, Katchalski-Katzir E. Isolation of peptides that inhibit binding of basic fibroblast growth factor to its receptor from a random phage-epitope library. Proc Natl Acad Sci USA. 1993;90:10643-7.

24. Togami K, Miyao A, Miyakoshi K, Kanehira Y, Tada H, Chono S. Efficient delivery to human lung fibroblasts (WI-38) of pirfenidone incorporated into liposomes modified with truncated basic fibroblast growth factor and its inhibitory effect on collagen synthesis in idiopathic pulmonary fibrosis. Biol Pharm Bull. 2015;38:270-6.

25. Kuehne J, Murphy RM. Synthesis and characterization of membraneactive GALA-OKT9 conjugates. Bioconjug Chem. 2001;12:742-9.

26. Nishimura Y, Takeda K, Ezawa R, Ishii J, Ogino C, Kondo A. A display of $\mathrm{pH}$-sensitive fusogenic GALA peptide facilitates endosomal escape from a bio-nanocapsule via an endocytic uptake pathway. J Nanobiotechnol. 2014;12:11.

27. Bartczak D, Muskens OL, Nitti S, Sanchez-Elsner T, Millar TM, Kanaras AG. Interactions of human endothelial cells with gold nanoparticles of different morphologies. Small. 2012;8:122-30.

28. Li W, Nicol F, Szoka FC Jr. GALA: a designed synthetic pH-responsive amphipathic peptide with applications in drug and gene delivery. Adv Drug Deliv Rev. 2004;56:967-85.

29. Liang W, Lam JKW. Endosomal escape pathways for non-viral nucleic acid delivery systems. In: Ceresa B, editor. Molecular regulation of endocytosis. Rijeka: InTech; 2012

30. Schach D, Globisch C, Roeters SJ, Woutersen S, Fuchs A, Weiss CK, Backus EHG, Landfester K, Bonn M, Peter C, Weidner T. Sticky water surfaces: helix-coil transitions suppressed in a cell-penetrating peptide at the airwater interface. J Chem Phys. 2014;141:22D517.

31. Lin BF, Missirlis D, Krogstad DV, Tirrell M. Structural effects and lipid membrane interactions of the $\mathrm{pH}$-responsive GALA peptide with fatty acid acylation. Biochemistry. 2012;51:4658-68.

32. Hermanson GT. Chapter 1 - functional targets. In: Hermanson GT, editor. Bioconjugate techniques, vol. 2. New York: Academic Press; 2008. p. $1-168$.

33. Rouser G, Siakotos AN, Fleischer S. Quantitative analysis of phospholipids by thin-layer chromatography and phosphorus analysis of spots. Lipids. 1966:1:85-6.

34. Lowry OH, Rosebrough NJ, Farr AL, Randall RJ. Protein measurement with the folin phenol reagent. J Biol Chem. 1951;193:265-75.

35. Jousma $\mathrm{H}$, Talsma $\mathrm{H}$, Spies F, Joosten J, Junginger $\mathrm{H}$, Crommelin D. Characterization of liposomes-the influence of extrusion of multilamellar vesicles through polycarbonate membranes on particle-size, particle-size distribution and number of bilayers. Int J Pharm. 1987;35:263-74.

36. DiMauro S. Mitochondrial diseases. Biochim Biophys Acta. 2004;1658:80-8.

37. Murphy MP, Smith RA. Targeting antioxidants to mitochondria by conjugation to lipophilic cations. Annu Rev Pharmacol Toxicol. 2007;47:629-56.

38. Lohman AW, Billaud M, Isakson BE. Mechanisms of ATP release and signalling in the blood vessel wall. Cardiovasc Res. 2012;95:269-80.

39. Chien S. Intracellular ATP delivery using highly fusogenic liposomes. Methods Mol Biol. 2010;605:377-91.

40. Akishiba M, Takeuchi T, Kawaguchi Y, Sakamoto K, Yu H, Nakase I, TakataniNakase T, Madani F, Graslund A, Futaki S. Cytosolic antibody delivery by lipid-sensitive endosomolytic peptide. Nat Chem. 2017;9:751-61.

41. Polito L, Bortolotti M, Mercatelli D, Battelli M, Bolognesi A. Saporin-S6: a useful tool in cancer therapy. Toxins. 2013;5:1698-722.

42. Goldman CK, Rogers BE, Douglas JT, Sosnowski BA, Ying W, Siegal GP, Baird A, Campain JA, Curiel DT. Targeted gene delivery to Kaposi's sarcoma cells via the fibroblast growth factor receptor. Cancer Res. 1997:57:1447-51.

43. Rancourt C, Rogers BE, Sosnowski BA, Wang M, Piche A, Pierce GF, Alvarez RD, Siegal GP, Douglas JT, Curiel DT. Basic fibroblast growth factor enhancement of adenovirus-mediated delivery of the herpes simplex 
virus thymidine kinase gene results in augmented therapeutic benefit in a murine model of ovarian cancer. Clin Cancer Res. 1998;4:2455-61.

44. Sosnowski BA, Gonzalez AM, Chandler LA, Buechler YJ, Pierce GF, Baird A. Targeting DNA to cells with basic fibroblast growth factor (FGF2). J Biol Chem. 1996;271:33647-53.

45. He QM, Wei YQ, Tian L, Zhao X, Su JM, Yang L, Lu Y, Kan B, Lou YY, Huang $\mathrm{MJ}$, et al. Inhibition of tumor growth with a vaccine based on xenogeneic homologous fibroblast growth factor receptor-1 in mice. J Biol Chem. 2003:278:21831-6.

46. Cai L, Qiu N, Li X, Luo K, Chen X, Yang L, He G, Wei Y, Chen L. A novel truncated basic fibroblast growth factor fragment-conjugated poly (ethylene glycol)-cholesterol amphiphilic polymeric drug delivery system for targeting to the FGFR-overexpressing tumor cells. Int J Pharm. 2011;408:173-82.

47. Nakase I, Futaki S. Combined treatment with a pH-sensitive fusogenic peptide and cationic lipids achieves enhanced cytosolic delivery of exosomes. Sci Rep. 2015;5:10112.

48. Morelli AE, Larregina AT, Shufesky WJ, Sullivan ML, Stolz DB, Papworth GD, Zahorchak AF, Logar AJ, Wang Z, Watkins SC, et al. Endocytosis, intracellular sorting, and processing of exosomes by dendritic cells. Blood. 2004; 104:3257-66.

49. Tian T, Wang $Y$, Wang $H$, Zhu Z, Xiao Z. Visualizing of the cellular uptake and intracellular trafficking of exosomes by live-cell microscopy. J Cell Biochem. 2010;111:488-96.

50. Thery C, Ostrowski M, Segura E. Membrane vesicles as conveyors of immune responses. Nat Rev Immunol. 2009;9:581-93.

51. Svensson KJ, Christianson HC, Wittrup A, Bourseau-Guilmain E, Lindqvist E, Svensson LM, Morgelin M, Belting M. Exosome uptake depends on ERK1/2-heat shock protein 27 signaling and lipid Raft-mediated endocytosis negatively regulated by caveolin-1. J Biol Chem. 2013;288:17713-24.

52. Simoes S, Slepushkin V, Gaspar R, de Lima MC, Duzgunes N. Gene delivery by negatively charged ternary complexes of DNA, cationic liposomes and transferrin or fusigenic peptides. Gene Ther. 1998:5:955-64.

53. Simoes S, Slepushkin V, Pires P, Gaspar R, de Lima MP, Duzgunes N. Mechanisms of gene transfer mediated by lipoplexes associated with targeting ligands or pH-sensitive peptides. Gene Ther. 1999;6:1798-807.

54. Simoes S, Slepushkin V, Pretzer E, Dazin P, Gaspar R, de Lima MC, Duzgunes N. Transfection of human macrophages by lipoplexes via the combined use of transferrin and pH-sensitive peptides. J Leukoc Biol. 1999:65:270-9.

55. Simoes S, Slepushkin V, Pires P, Gaspar R, de Lima MC, Duzgunes N. Human serum albumin enhances DNA transfection by lipoplexes and confers resistance to inhibition by serum. Biochim Biophys Acta. 2000;1463:459-69.

56. Futaki S, Masui Y, Nakase I, Sugiura Y, Nakamura T, Kogure K, Harashima H. Unique features of a $\mathrm{pH}$-sensitive fusogenic peptide that improves the transfection efficiency of cationic liposomes. J Gene Med. 2005;7:1450-8.

57. Kobayashi S, Nakase I, Kawabata N, Yu H-H, Pujals S, Imanishi M, Giralt E, Futaki S. Cytosolic targeting of macromolecules using a pH-dependent fusogenic peptide in combination with cationic liposomes. Bioconjug Chem. 2009;20:953-9.

58. Egorov T, Svenson A, Ryden L, Carlsson J. Rapid and specific method for isolation of thiol-containing peptides from large proteins by thiol-disulfide exchange on a solid support. Proc Natl Acad Sci USA. 1975;72:3029-33.

59. Boyer C, Liu J, Wong L, Tippett M, Bulmus V, Davis T. Stability and utility of pyridyl disulfide functionality in RAFT and conventional radical polymerizations. J Poly Sci Part A. 2008;46:7207-24.

60. Matsumoto N, Gonzalez-Toro D, Chacko R, Maynard H, Thayumanavan S. Synthesis of nanogel-protein conjugates. Polym Chem. 2013:4:2464-9.

61. Josephson L, Tung C, Moore A, Weissleder R. High-efficiency intracellular magnetic labeling with novel superparamagnetic-tat peptide conjugates. Bioconjug Chem. 1999;10:186-91.
62. Wen X, Wang K, Zhao Z, Zhang Y, Sun T, Zhang F, Wu J, Fu Y, Du Y, Zhang L, et al. Brain-targeted delivery of trans-activating transcriptor-conjugated magnetic PLGA/lipid nanoparticles. PLoS ONE. 2014;9:e106652.

63. Kerr J, Schlosser J, Griffin D, Wong D, Kasko A. Steric effects in peptide and protein exchange with activated disulfides. Biomacromolecules. 2013;14:2822-9.

64. Heath T. Covalent attachment of proteins to liposomes. Methods Enzymol. 1987;149:111-9.

65. Amitay Y, Shmeeda H, Patil Y, Gorin J, Tzemach D, Mak L, Ohana P, Gabizon A. Pharmacologic studies of a prodrug of mitomycin $C$ in pegylated liposomes (promitil(A (R))): high stability in plasma and rapid thiolytic prodrug activation in tissues. Pharm Res. 2016;33:686-700.

66. Etzerodt T, Trier S, Henriksen J, Andresen T. A GALA lipopeptide mediates $\mathrm{pH}$ - and membrane charge dependent fusion with stable giant unilamellar vesicles. Soft Matter. 2012;8:5933-9.

67. de Duve C, de Barsy T, Poole B, Trouet A, Tulkens P, Van Hoof F. Commentary. Lysosomotropic agents. Biochem Pharmacol. 1974;23:2495-531.

68. Baio JE, Schach D, Fuchs AV, Schmüser L, Billecke N, Bubeck C, Landfester K, Bonn M, Bruns M, Weiss CK, Weidner T. Reversible activation of $\mathrm{pH}$-sensitive cell penetrating peptides attached to gold surfaces. Chem Commun (Camb). 2015;51:273-5.

69. Okamoto Y, Taguchi K, Yamasaki K, Sakuragi M, Kuroda SI, Otagiri M. Albumin-encapsulated liposomes: a novel drug delivery carrier with hydrophobic drugs encapsulated in the inner aqueous core. J Pharm Sci. 2018;107:436-45

70. Cauwels A, Rogge E, Vandendriessche B, Shiva S, Brouckaert P. ExtracelIular ATP drives systemic inflammation, tissue damage and mortality. Cell Death Dis. 2014;5:e1102.

71. Fleiner M, Benzinger P, Fichert T, Massing U. Studies on protein-liposome coupling using novel thiol-reactive coupling lipids: influence of spacer length and polarity. Bioconjug Chem. 2001;12:470-5.

72. Reulen SW, Brusselaars WW, Langereis S, Mulder WJ, Breurken M, Merkx M. Protein-liposome conjugates using cysteine-lipids and native chemical ligation. Bioconjug Chem. 2007;18:590-6.

73. Mangold HK. Thin-layer chromatography of lipids. J Am Oil Chem Soc. 1961:38:708-27.

74. Zinzadze C. Colorimetric methods for the determination of phosphorus. Ind Eng Chem Anal Ed. 1935;7:227-30.

75. Lasic DD. The mechanism of vesicle formation. Biochemical Journal. 1988;256:1-11

76. Page B, Page M, Noel C. A new fluorometric assay for cytotoxicity measurements in-vitro. Int J Oncol. 1993;3:473-6.

77. Nakayama GR, Caton MC, Nova MP, Parandoosh Z. Assessment of the Alamar Blue assay for cellular growth and viability in vitro. J Immunol Methods. 1997;204:205-8.

78. Nociari MM, Shalev A, Benias P, Russo C. A novel one-step, highly sensitive fluorometric assay to evaluate cell-mediated cytotoxicity. J Immunol Methods. 1998;213:157-67.

79. Rampersad SN. Multiple applications of alamar blue as an indicator of metabolic function and cellular health in cell viability bioassays. Sensors (Basel, Switzerland). 2012;12:12347-60.

80. Schneider CA, Rasband WS, Eliceiri KW. NIH Image to ImageJ: 25 years of image analysis. Nat Methods. 2012;9:671-5.

\section{Publisher's Note}

Springer Nature remains neutral with regard to jurisdictional claims in published maps and institutional affiliations. 